\title{
Sialic Acid Content of Erythrocytes in Normal Individuals and Patients With Certain Hematologic Disorders
}

\author{
D. Aminoff, J. Anderson, L. Dabich, and W.D. Gathmann \\ Departments of Internal Medicine (Simpson Memorial Institute) and Biological Chemistry, \\ The University of Michigan, Ann Arbor
}

\begin{abstract}
The sialic acid content of erythrocytes from healthy individuals of different blood types and of patients with known hematological disorders has been determined. The sialic acid was completely released enzymatically with sialidase and quantitated by the thiobarbituric acid method. The sialic acid content of erythrocytes was constant irrespective of $\mathrm{ABO}$ blood type, or anticoagulant used; viz, $0.85-0.92 \mu \mathrm{moles} / \mathrm{ml}$ of packed ery throcytes or $46-53 \times 10^{6}$ sialyl residues per cell. Deviations from these normal values were obtained with erythrocytes from patients with a variety of hematological disorders. Patients with the following disorders have significantly $(P<0.01)$ lower sialic acid values compared to erythrocytes from healthy individuals (given in the order of decreasing sialic acid content): sickle cell anemia, acute lymphocy tic leukemia, chronic ly mphocy tic leukemia, acute myelomonocy tic leukemia, non-Hodgkin lymphocy tic lymphoma, chronic granulocy tic leukemia, acute myelocy tic leukemia, leukemia, and Hodgkin disease.
\end{abstract}

Key words: ery throcyte analysis, sialic acid, hematologic diseases, cell membrane

\section{INTRODUCTION}

Sialic acid has been detected on the surface of erythrocytes of all species examined, including man [1-4]. The type and amount of sialic acid vary appreciably in the different species; eg, in the dog there are $72 \times 10^{6}$ sialyl residues/erythrocyte, whereas in the rabbit there are $3 \times 10^{6}$ residues/erythrocyte $[4]$.

Received for publication April 23, 1980; accepted August 12, 1980.

Address reprint requests to David Aminoff, Simpson Memorial Institu te, The University of Michigan, Ann Arbor, MI 48109. 
It has now been shown in a number of laboratories that the removal of the sialyl residues results in a loss of viability of the erythrocytes in circulation as demonstrated by ${ }^{51} \mathrm{Cr}$-labeling studies [see reference 4 for review of literature]. We have extended these observations to show that it is true of a number of mammalian species irrespective of the type or amount of sialic acid present [4]. Since the phenomenon is not observed with chicken erythrocytes [4] , it can be assumed that the sequestration of asialo-erythrocytes jnvolves a specific mechanism and is not merely due to the loss of the overall total negative charge of the erythrocyte.

We have further shown that in the dog, removal of approximately $10 \%$ of the total sialic acid is sufficient to result in almost complete sequestration of the asialo-erythrocytes [4]. The threshold value of $10 \%$ obtains added significance in light of previous observations that young erythrocytes contain $10-15 \%$ more sialic acid than old erythrocytes $[5,6]$. We therefore subscribed to the hypothesis that the sialic acid of erythrocytes is physiologically involved in the maintenance of erythrocytes in circulation and any drop from the threshold number of residues per erythrocyte might represent the signal for the sequestration of the effete erythrocytes from circulation. It was to ascertain the validity of this hypothesis that the following survey was undertaken to determine the constancy of the sialic acid content of ery throcytes in healthy individuals and to look for possible divergence in hematological disorders. A preliminary report has already appeared [7] .

\section{MATERIALS AND METHODS}

The sialidase used for these investigations was prepared and assayed as previously described [4]. In that study we had demonstrated that, under the conditions of assay, the sialic acid released represented the total bound sialic acid present on the red cell surface.

Blood from normal individuals and from patients was obtained in accordance with the University Hospital guidelines and accreditation regarding "Research Projects Involving Human Subjects."

Blood from healthy individuals represented the blood obtained from University Hospital staff and volunteer blood donors with no known hematological disorders. Patient blood samples were obtained from a random selection of patients with hematological disorders attending the Hematology-Oncology Clinic, University of Michigan Medical Center. In all cases venous blood was drawn into Vacutainers (Becton-Dickinson, Orangeburg, NY), usually with EDTA* or heparin as the anticoagulant. Samples were stored for no longer than 24 hours at $4^{\circ} \mathrm{C}$ and assayed as previously described, with care taken that the buffy coat was completely removed [4]. The results can be expressed either as $\mu$ moles of sialic acid per $\mathrm{ml}$ of packed erythrocytes, or as number of sialic acid residues per erythrocyte.

\section{RESULTS}

\section{Optimal Conditions for the Release of Sialic Acid}

Although the conditions for optimal release of sialic acid have previously been established for animal erythrocytes, they have been repeated here to reconfirm their applicability to human erythrocytes (Figs. 1 and 2).

\footnotetext{
*Abbreviations: $\mathrm{ACD}=$ acid citrate dextrose $; \mathrm{CPD}=$ citrate phosphate dextrose $; \mathrm{DF}=$ degrees of freedom; EDTA $=$ ethylenediamine tetra-acetate $\mathrm{SD}=$ standard deviation.
} 


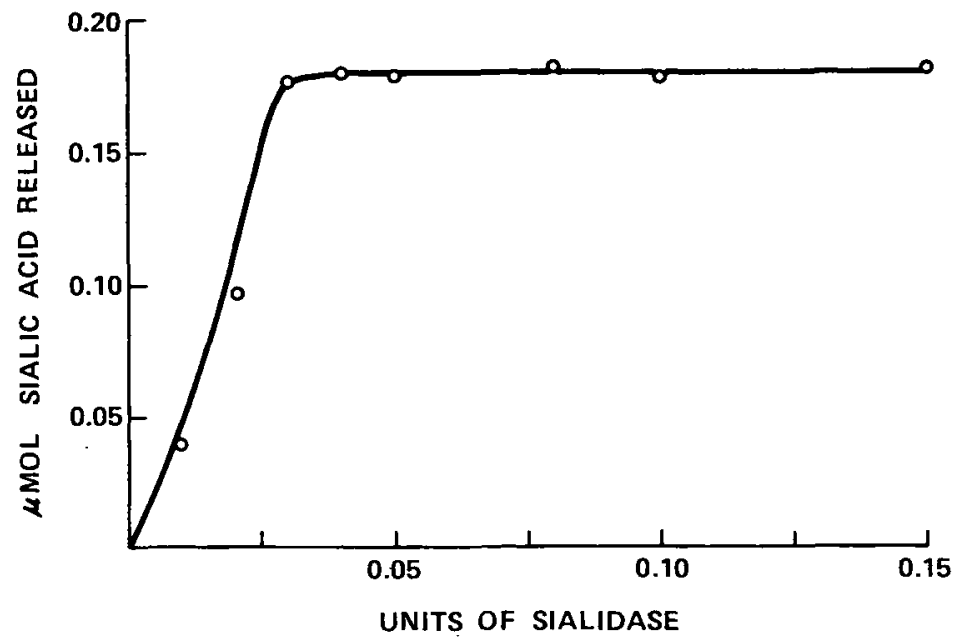

Fig. 1. Release of sialic acid from hyman erythrocytes as a function of sialidase concentration. Onefifth $\mathrm{ml}$ of packed ery throcytes was incubated at $37^{\circ}$ for 30 minutes with varying amounts of enzyme under the standard assay conditions.

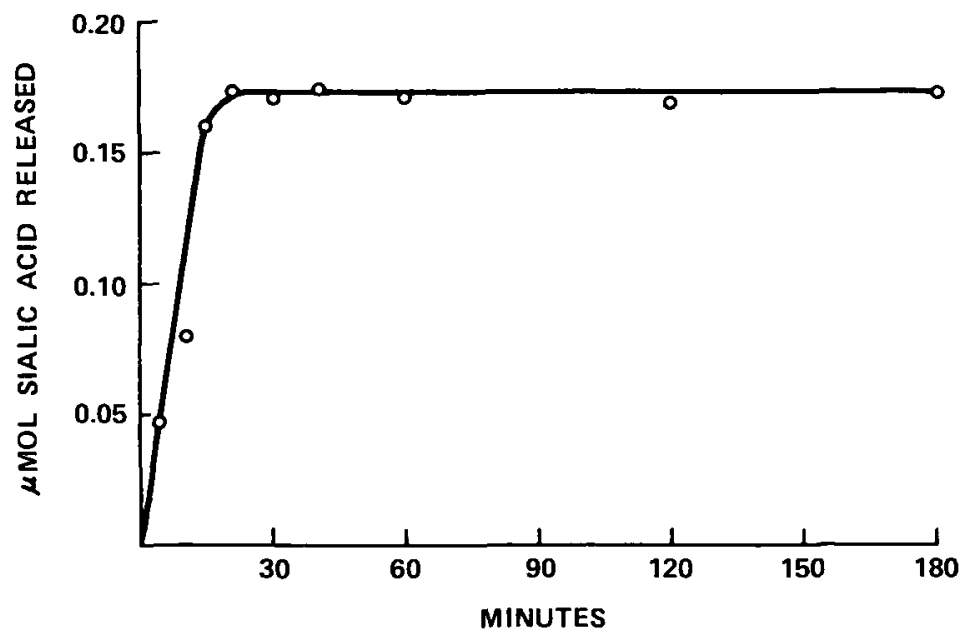

Fig. 2. Release of sialic acid from human erythrocytes with sialidase as a function of time. Fourhundredths of a unit of sialidase were incubated with $0.2 \mathrm{ml}$ of packed erythrocytes at $37^{\circ}$ for varying periods of time.

\section{Effect of Anticoagulant}

A number of different anticoagulants were used: heparin, ACD, CPD and EDTA. Blood from one individual was collected in to each of the different anticoagulants. The sialic acid content was determined on the first day and after four days of storage at $4^{\circ} \mathrm{C}$. Similar experiments were performed with blood of different species. The erythrocytes were then centrifuged and washed in an identical manner, and the sialic acid content of the erythrocytes was determined. No difference was found in the sialic acid content of the different specimens stored in the different anticoagulants (Table I). 
TABLE I. Comparison of Sialic Acid Content of Blood Withdrawn and Stored in Different Anticoagulants

Sialic acid residues $\times 10^{-6} /$ ery throcy te

$($ mean $\pm \mathrm{SD})$

\begin{tabular}{llllll}
\cline { 3 - 6 } Species & Day & Heparin & ACD & CPD & EDTA \\
\hline Human & 1 & $51.5 \pm 0.5$ & $51.1 \pm 0.4$ & $51.8 \pm 0.2$ & $51.2 \pm 0.1$ \\
Human & 4 & $49.3 \pm 0.6$ & $49.5 \pm 0.1$ & $48.3 \pm 0.1$ & $47.5 \pm 0.6$ \\
Dog & 1 & $65.0 \pm 1.0$ & $65.0 \pm 0$ & $67.0 \pm 1.0$ & $64.5 \pm 0.5$ \\
Dog & 4 & $62.5 \pm 0.5$ & $62.5 \pm 1.5$ & $62.0 \pm 1.0$ & $63.0 \pm 1.0$ \\
Chicken & 1 & $13.5 \pm 0.5$ & $14.0 \pm 0$ & $13.5 \pm 0.5$ & $14.5 \pm 0.5$ \\
\hline
\end{tabular}

\section{Effect of Storage of Blood Under Blood Bank Conditions}

A half unit of blood was withdrawn from each of two volunteers and collected in CPD plastic packs. The units were stored in a refrigerator and subjected to the routine manipulation of blood stored in a blood bank. Aliquots of blood were removed at regular intervals over a period of three weeks, and the sialic acid content of the erythrocytes was determined. Figure 3 shows the typical curves obtained. There is a rapid initial loss of sialic acid in the first 24 hours, which then stabilizes over the next three weeks (Fig. 3A and B). With care in handling, this initial loss of sialic acid can be greatly diminished.

\section{Sialic Acid Content of Erythrocytes From Individuals of Different ABO Blood Types and Patients With Certain Hematological Disorders}

Table II and Figure 4 show the detailed distribution of sialic acid content of erythrocytes from 65 healthy individuals and 121 patients. In some patients $(22 / 121)$ blood was available for analysis on more than one occasion. There was no appreciable change in the sialic acid content in most cases. There were a few exceptions to this generalization where the sialyl residues/ery throcyte varied by more than $5 \%$; eg, two patients with Hodgkin disease with values ranging from 39.7 to $43.9 \times 10^{6}$ and 42.5 to $45.0 \times 10^{6}$, respectively; 41.2 to $44.8 \times 10^{6}$ in one acute myelomonocytic leukemia patient, and 44.9 to $48.9 \times 10^{6}$ in a patient with non-Hodgkin lymphocytic lymphoma. A wide distribution of sialic acid content is observed over the spectrum of hematological disorders. But if we use the interval determined by the mean \pm 2 SD of the sialic acid values of normal blood as the "healthy" range, then distinct categories become apparent (Table II, Fig. 4).

The mean sialic acid content on erythrocytes of patients with hematological disorders was compared to the mean found in the erythrocytes of healthy individuals by applying a two-tailed t-test* for equal population means with a 0.01 level of significance [8]. The results (Table II) show that all of the disorders, with the exception of erythroleukemia, agnogenic myeloid metaplasia, idiopathic thrombocytopenic purpura, subacute granulocytic leukemia, multiple myeloma, and autoimmune hemolytic anemia had sialic acid means that

\footnotetext{
* The hypothesis that the population means are statistically identical is accepted whenever the critical Student's t-value is greater than the calculated (positive) t-value. Conversely, this hypothesis is rejected whenever the critical $t$-value is less than the experimental value.
} 

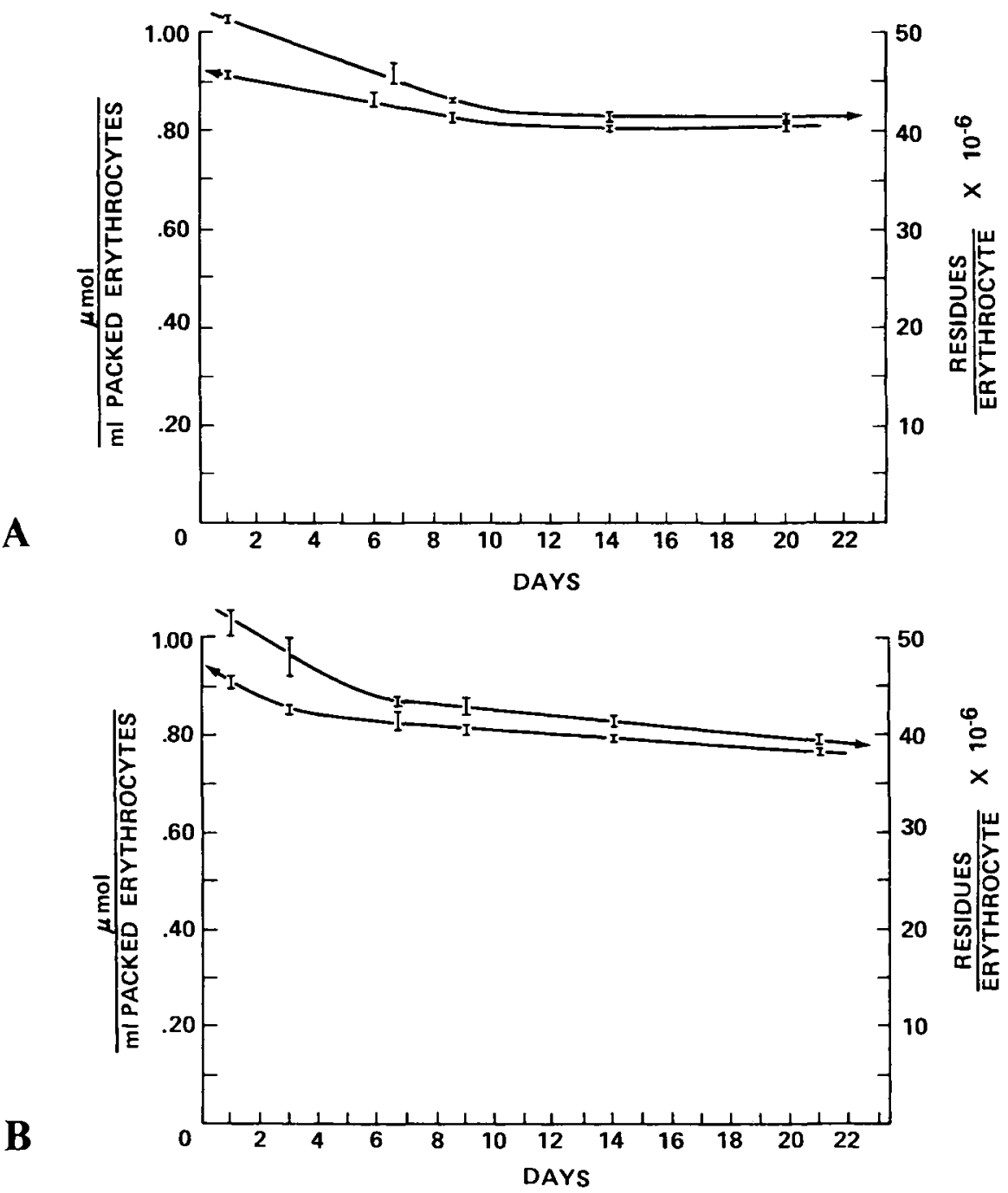

Fig. 3. Sialic acid content of human erythrocytes stored under blood bank conditions. One half unit of blood was drawn from two individuals of blood types A (3A) and 0 (3B) by standard hospital procedure. Blood was stored in CPD at $4^{\circ}$ under standard blood bank conditions. Samples of the well mixed blood were withdrawn over a three week period and the washed cells assayed for their sialic acid content in the usual manner.

differed significantly from those of healthy individuals. Furthermore, all but idiopathic thrombocytopenic purpura and agnogenic myeloid metaplasia erythrocytes differed from normal at $\mathbf{P}<0.05$. The magnitude of the differences between the means is a useful objective measure for comparison.

\section{DISCUSSION}

As is apparent from Figures 1 and 2, under the conditions of the assay we measure the total sialic acid that can be released with sialidase. We have previously shown [4] that this 
Healthy Type A

Healthy Type B

Healthy Type AB

Healthy Type 0

Total Healthy Cells

Erythroleukemia

Agnogenic Myoloid Motaplasia

Idlopathic Thrombocytopenic Purpura

Sickle Cell Anemis

Subacute Granulocytic Leukemia

Multiple Myeloma

Acute Lymphocytic Leukemia

Chronic Lymphocytic Loukemia

Autoimmune Hemolytic Anemia

95\% Normal Range
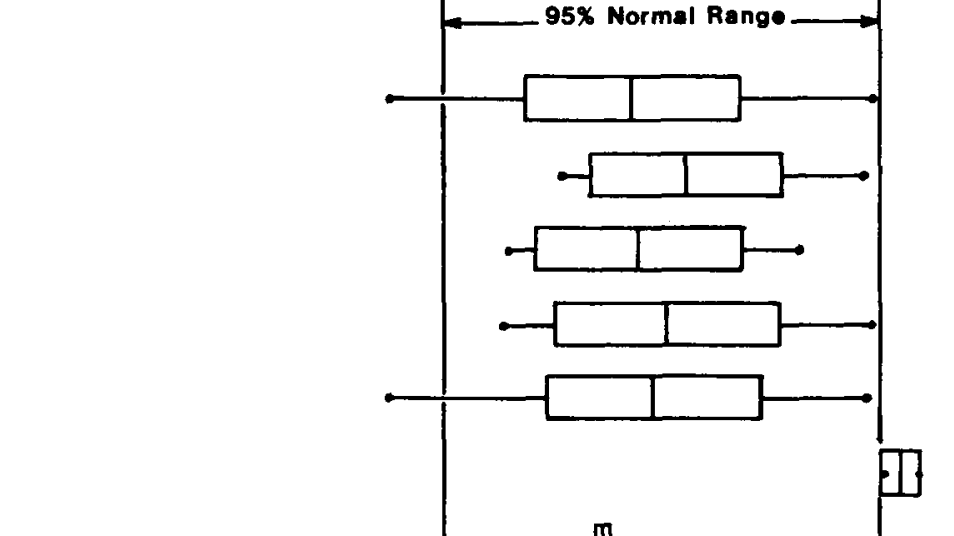

Acuto Myelomonocytic Loukemia

Non-Hodgkin's Lymphocytic Lymphoma

Chronic Granulocytic Leukemia

Acute Myelocytic Loukemia

Loukemia

\section{Hodgkin's Disease}

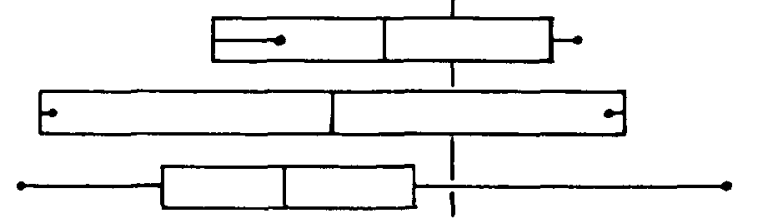

Fig. 4. Distribution of sialic acid content in erythrocytes of healthy individuals of blood type A, B, AB and $\mathrm{O}$ as well as from patients with certain hematological disorders. The rectangular box represents the mean \pm S.D. The enclosed circles represent the observed high and low values for each distribution. The $95 \%$ normal range for healthy individuals $\bar{X} \pm 2$ (S.D.).

is indeed a measure of the total sialic acid on the erythrocyte surface. Furthermore, the anticoagulant used to collect and store the blood does not affect the determination of the total sialic acid on the erythrocyte surface. A certain amount of erythrocyte surface sialic acid is lost during storage in the anticoagulants, which in citrate/phosphate/dextrose becomes 
TABLE II. Sialic Acid Residues $\times 10^{-6} /$ Erythrocyte

\begin{tabular}{|c|c|c|c|c|c|c|c|c|}
\hline \multirow[b]{2}{*}{ Designation } & \multirow[b]{2}{*}{$\mathbf{N}$} & \multirow[b]{2}{*}{$\mathrm{x}$} & \multirow[b]{2}{*}{$\mathrm{M}$} & \multirow[b]{2}{*}{ SD } & \multicolumn{4}{|c|}{ Hypothesis test $(\alpha=0.01)^{\mathrm{a}}$} \\
\hline & & & & & $\mathrm{CV}$ & DF & tc & $\mathbf{t}$ \\
\hline Healthy type A & 23 & 49.4 & 49.3 & 1.7 & 3.44 & & & \\
\hline Healthy type B & 8 & 50.1 & 50.0 & 1.5 & 2.99 & & & \\
\hline Healthy type $A B$ & 7 & 49.5 & 49.9 & 1.6 & 3.23 & & & \\
\hline Healthy type $O$ & 27 & 49.9 & 50.1 & 1.8 & 3.60 & & & \\
\hline Total heal thy cells & 65 & 49.7 & 49.7 & 1.7 & 3.42 & & & \\
\hline Erytholeukemia & 2 & 53.4 & 53.4 & 0.3 & 0.56 & 65 & 2.65 & 2.52 \\
\hline $\begin{array}{l}\text { Agnogenic myeloid } \\
\text { metaplasia }\end{array}$ & 3 & 48.7 & 48.7 & 0.1 & 0.21 & 66 & 2.65 & 1.01 \\
\hline Idiopathic thrombo- & & & & & & & & \\
\hline cytopenic purpura & 7 & 48.4 & 48.8 & 2.1 & 4.34 & 70 & 2.65 & 1.88 \\
\hline Sickle cell anemia & 14 & 48.3 & 48.4 & 1.8 & 3.73 & 77 & 2.64 & 2.77 \\
\hline Subacute granulo- & & & & & 4.39 & 68 & 265 & 237 \\
\hline & $\begin{array}{l}5 \\
5\end{array}$ & $\begin{array}{l}47.8 \\
47.8\end{array}$ & $\begin{array}{l}48.2 \\
47.9\end{array}$ & $\begin{array}{l}2.1 \\
1.0\end{array}$ & $\begin{array}{l}4.39 \\
2.09\end{array}$ & $\begin{array}{l}00 \\
68\end{array}$ & $\begin{array}{l}2.65 \\
2.65\end{array}$ & 2.46 \\
\hline $\begin{array}{l}\text { Multiple myeloma } \\
\text { Acute lymphocytic }\end{array}$ & & & & & & & & \\
\hline leukemia & 6 & 47.8 & 47.5 & 1.1 & 2.30 & 69 & 2.65 & 2.68 \\
\hline $\begin{array}{l}\text { Chronic lympho- } \\
\text { cytic leukemia }\end{array}$ & 10 & 47.5 & 47.7 & 1.3 & 2.74 & 73 & 2.64 & 3.91 \\
\hline $\begin{array}{l}\text { Autoimmune } \\
\text { hemoly tic anemia }\end{array}$ & 3 & 47.3 & 47.2 & 0.4 & 0.85 & 66 & 2.65 & 2.41 \\
\hline $\begin{array}{l}\text { Acute myelomono- } \\
\text { cytic leukemia }\end{array}$ & 5 & 46.9 & 46.7 & 1.8 & 3.83 & 68 & 2.65 & 3.54 \\
\hline $\begin{array}{l}\text { Non-Hodgkin } \\
\text { lymphocytic }\end{array}$ & & & & & & & & \\
\hline lymphoma & 27 & 45.9 & 45.8 & 2.3 & 5.01 & 90 & 2.63 & 8.77 \\
\hline $\begin{array}{l}\text { Chronic granulocytic } \\
\text { leukemia }\end{array}$ & 7 & 45.8 & 45.9 & 1.4 & 3.07 & 70 & 2.65 & 5.84 \\
\hline Acute myelocytic & & & & & & & & \\
\hline $\begin{array}{l}\text { leukemia } \\
\text { Leukemia }\end{array}$ & $\begin{array}{l}3 \\
4\end{array}$ & $\begin{array}{l}45.4 \\
44.5\end{array}$ & $\begin{array}{l}44.0 \\
44.5\end{array}$ & $\begin{array}{l}2.6 \\
4.6\end{array}$ & $\begin{array}{r}5.73 \\
10.34\end{array}$ & $\begin{array}{l}66 \\
67\end{array}$ & $\begin{array}{l}2.65 \\
2.65\end{array}$ & $\frac{4.20}{5.24}$ \\
\hline Hodgkin disease & 20 & 43.8 & 44.0 & 2.1 & 4.79 & 83 & 2.64 & 12.82 \\
\hline
\end{tabular}

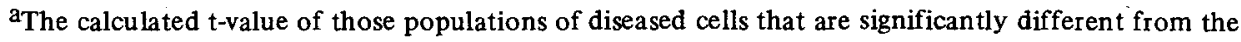
population of healthy cells using a two-tailed t-test for population are underlined.

quite marked when the blood is drawn and stored under conditions of the blood bank (Figs. 3A and B). The experiments described here were therefore performed with fresh blood obtained from healthy individuals and patients and assayed within 24 hours.

The values for sialic acid content of erythrocytes in any given individual remain remarkably constant on repeated determination. However, there is usually more variation between individuals in sialic acid content of erythrocytes. Using approximately $95 \%$ limits gives a normal range of $46-53 \times 10^{6}$ sialyl residues per erythrocyte for healthy individuals.

Changes in the sialic acid content of erythrocytes can be attributed to 1) variation in the sialic acid content present at the end of the oligosaccharide chains of the glycoconjugates, 2) changes in the type and amount of sialoglycoconjugates in the erythrocyte membrane, and/or 3) extension or diminution of the erythrocy te membrane consisting of sialoglycoconjugates, proteins, and lipids, thereby affecting the analytical value of sialic acid content per erythrocyte as well as the other carbohydrate components $[9,10]$.

Examples of 1) have been observed in viral infection with the myxo-influenza group of viruses when the infection is accompanied by a loss of erythrocytes from the circulation 
$[11,12]$. The second type is illustrated by studies on individuals who are En(a-), where the sialic acid content of the erythrocytes has been shown to be as low as $33 \%$ of normal [13]. The red cells of these individuals appeared to have a normal survival time in circulation. This would be seemingly incompatible with the hypothesis proposed [4] that a low sialic acid content would result in the loss of viability. Electrophoretic analysis of the erythrocyte membranes of En(a-) individuals, however, demonstrated almost total absence of a specific sialo-glycoprotein, glycophorin A [14]. Thus, in this phenotype, even though the number of sialyl residues on the ery throcyte surface is decreased, there is no increase in the number of oligosaccharide stubs terminating in galactosyl residues, a requirement of the hypothesis for more rapid sequestration from circulation [4].

Low erythrocytic sialic acid levels have previously been observed in diabetes mellitus patients, and it has been claimed that this low level can be brought back to normal values by treatment with insulin [15] in paroxysmal nocturnal hemoglobinuria [16], sickle cell anemia [17], and thalassemia $[18,19]$.

Erythrocyte membrane of thalassemic patients has been reported to have $25 \%$ less sialic acid than that found in normals. Kahane et al subsequently demonstrated that the young erythrocytes released from the bone marrow have close to normal sialoglycoproteins and that old thalassemic erythrocytes have $50 \%$ of their sialic acid [20].

Studies are underway in our laboratories to determine the causes of the low and high sialic acid content of erythrocytes in certain of the above discussed hematological disorders.

\section{CONCLUSIONS}

1) Optimal conditions for the collection of blood and determination of the total sialic acid of erythrocytes are presented.

2) The normal range of sialic acid residues per erythrocyte in 65 healthy individuals is $49.7 \times 10^{6} \pm 1.7$, irrespective of ABO blood type.

3) From the limited number of patients with hematological disorders examined, we have found that the range of sialic acid residues per erythrocyte varies from higher than normal in erythroleukemics $\left(53.4 \times 10^{6} \pm 0.3\right)$, and from significantly lower than normal $(\mathrm{P}<0.01)$ in the following disorders, given in the order of decreasing sialic acid content: sickle cell anemia $\left(48.3 \times 10^{6} \pm 1.8\right)$, acute lymphocytic leukemia, chronic lymphocy tic leukemia, acute myelomonocy tic leukemia, non-Hodgkin lymphocytic lymphoma, chronic granulocytic leukemia, acute myelocytic leukemia, leukemia, and Hodgkin disease (43.8 $\left.\times 10^{6} \pm 2.1\right)$.

More in-depth investigations of the cause(s) of low sialic acid content in certain hematological disorders are under way.

\section{ACKNOWLEDGMENTS}

This project was supported in part by grant HL AM 17881 from the National Institutes of Health.

We wish to thank W.J. Judd, Department of Pathology, for providing us with many samples of normal blood of known pheriotype; and K. Guire, G. Nace, G. Nordby, and R. Wolfe for consultations regarding computer applications and statistical analysis of the data. 


\section{REFERENCES}

1. Yamakawa T, Suzuki S: The chemistry of lipids of post hemolytic residue or stroma of erythrocytes. I. Concerning the ether insoluble lipids of lyophilized horse blood stroma. J Biochem (Tokyo) 38:199, 1951; IV. Distribution of lipid-hex osamine and lipid hemataminic acid in red blood cells of various species of animals. J Biochem (Tokyo) 40:7, 1953.

2. Klenk E, Lauenstein K: Uber Die Zuckerhaltingen lipoide des Erythrocytenstromas von Mensch und Rind. Hoppe Seylers Z Physiol Chem 291:249, 1952.

3. Eylar EH, Madoff MA, Brody OV, Oncley JL: The contribution of sialic acid to the surface charge of the ery throcyte. J Biol Chem 237:1992, 1962.

4. Aminoff D, Bell WC, Fulton I, Ingebrigtsen N: Effect of sialidase on the viability of erythrocytes in circulation. Am J Hematol 1:419, 1976.

5. Greenwalt TJ, Steane EA, Pine NE: Changes in erythrocyte surface antigens with aging in vivo. In Jamieson GA and Greenwalt TJ (eds): "Glycoproteins of Blood Cells and Plasma." Philadelphia: Lippincott, 1971, p 235.

6. Bax ter A, Beeley JG: Changes in surface carbohydrates of human ery throcytes aged in vivo. Biochem Soc Trans 3:134, 1975 .

7. Anderson J, Dabich L, Aminoff D: Sialic acid content of erythrocytes in normal individuals and patients with hematological disorders. Clin Res 26:667A, 1978.

8. Diem K (ed): Documenta Geigy, Scientific Tables, Ed. 6, 1962, p 32.

9. Gattegno L, Bladier D, Garnier M, Cornillot P: Changes in carbohydrate content of surface membranes in human ery throcytes during aging. Carbohydrate Res 52:197, 1976.

10. Baxter A, Beeley JG: Surface carbohydrates in aged ery throcytes. Biochem Biophys Res Commun 83:466. 1978.

11. Stewart WB, Petenyi CW, Rose HM: The survival time of canine ery throcytes modified by influenza virus. Blood 10:228, 1955.

12. Gardner $\mathrm{E}$, Wright $\mathrm{C}$, Williams $\mathrm{BZ}$ : The survival of virus treated erythrocy tes in normal and splenectomized rabbits. J Lab Clin Med 58:743, 1961.

13. Furuhjelm U, Myllyla G, Nevanlinna HR, Nordling S, Pirkola A, Gavin J, Gooch A, Sanger R, Tippett $P$ : The red cell phenotype En(a-) and anti-En ${ }^{\mathrm{a}}$ : Serological and phy sico-chemical aspects. Vox Sang 17:256, 1969.

14. Gahmberg CH, Myllyla G, Leikola J, Pirkola A, Nordling S: Absence of the major sialoglycoprotein in the membrane of human En(a-) erythrocytes and increased glycosylation of band 3 . J Biol Chem $251: 6108,1976$.

15. Chakrabarti T, Pawar RB, Shastri MG, Choudhary DR, Chakrabarti CH, Dias PD: N-acetylneuraminic acid level in the ery throcy te membrane and serum of patients suffering from diabetes mellitus. Indian $\mathrm{J}$ Med Res 60:1038, 1972.

16. Balduini LC, Tira F, Ascari E, Balduini C: Glycopeptides of ery throcy te membranes in some hematological disorders. Acta Hematol 55:282, 1976.

17. Riggs MG, Ingram VM: Differences in ery throcy te membrane proteins and glycoproteins in sickle cell disease. Biochem Biophys Res Commun 74:191, 1977.

18. Kahane I, Rachmilewitz EA : Alterations in the red blood cell membrane and the effect of vitamin E on osmotic fragility in $\beta$-thalassemia major. Israel J Med Sci 12:11, 1976.

19. Kahane I, Polliack A, Rachmilewitz EA, Bayer EA, Skutelsky E: Distribution of sialic acids of the red blood cell membrane in $\beta$-thalassaemia. Nature 271:674, 1978.

20. Kahane I, Ben-Chetrit E, Shifter A, Rachmilewitz EA: The ery throcy te membrane in $\beta$-thalassaemia lower sialic acid levels in glycophorin and absence of sialidase activity. Biochim Biophys Acta (in press). 